International Journal of Social Sciences and Humanities
Available online at http://sciencescholar.us/journal/index.php/ijssh
Vol. 3 No. 2, August 2019, pages: $217 \sim 223$
e-ISSN: 2550-7001, p-ISSN: 2550-701X
https://doi.org/10.29332/ijssh.v3n2.317

\title{
Sensory Playful Corners on Stimulation of Children from One to Three Years
}

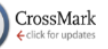 \\ Rosa Delfina Giler Giler a , Telly Yarita Macías Zambrano b ${ }^{\text {, }}$ Fabián Enrique Vera Anzules ${ }^{c}$, Veronica \\ Del Pilar Zambrano Burgos ${ }^{\mathrm{d}}$
}

Article history: Received 09 December 2018, Accepted: 30 April 2019, Published: 19 August 2019

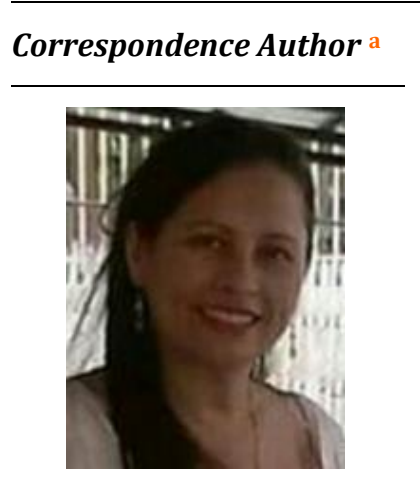

Keywords

childhood;

corners;

playful;

sensory;

stimulation;

\begin{abstract}
Despite the growing tendency to create playful corners on the part of the MIES and the MINEDUC, in the CDI there continues to be an urgent need for change in the actions of the educators, with respect to how the subject of sensory activities is being handled in the stimulation of children in their first years of life and thus implement meaningful learning, the problem focuses on the lack of sensory playful corners in perceptual stimulation The study was applied to 20 educators of 5 care units of the modality Child Development Center (CDI) of several rural sectors of the Portoviejo canton, having as objective to determine the use of sensory playful corners in the stimulation of children from 1 to 3 years. The results of this work showed that there are no sensory playful corners and that educators lack knowledge about the importance of creating these spaces and making them available to children for their learning, reaching the conclusion that there is a need to create an innovative guide with content sessions, skills, play materials for the corners of visual, auditory, gustatory, olfactory and tactile perception.
\end{abstract}

e-ISSN: 2550-7001, p-ISSN: 2550-701X ${ }^{\odot}$ Copyright 2019. The Author. SS Journals Published by Universidad Técnica de Manabí. This is an open-access article under the CC BY-SA 4.0 license (https://creativecommons.org/licenses/by-sa/4.0/) All rights reserved.

\section{Contents}

Abstract

1. Introduction ... 218

2. Materials and Methods 218

3. Results and Discussions 219

4. Conclusion 221 


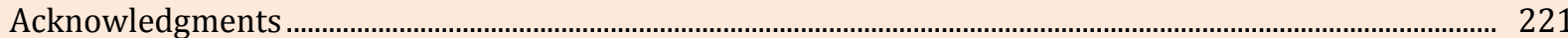

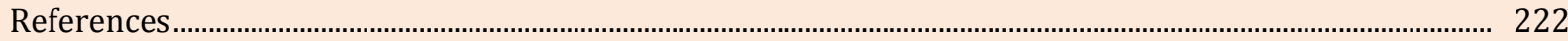

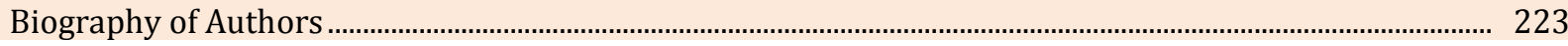

\section{Introduction}

Sensory perception strengthened through the use of the senses such as taste, touch, smell, hearing and vision, form the set of organs that fulfill specific functions, such as understanding, communicating, feeding, expressing, observing, in short, they are the perfect links between the inside of the human being with the outside, which helps to remain in the constant dynamic of the survival of man.

Such a point of view, in the present work is considered on the educational expectations for which emphasis is placed on bringing to the initial education classrooms a strengthening tool not only of the teaching-learning process, but of constructing for the child a world full of situations where he can develop his senses after the search for knowledge, as well as his integral development, that is, to be with an integrity of knowledge, attitudes and valid abilities that helps him to understand his environment. For most educators it is difficult to find the right way to work in the CDI, changing passivity by activity, for this reason over five chapters the research that is explained below is consolidated:

The study proposes an idea of change, a reference of work with infants that promotes the development of perception with their senses that allow them to achieve their integral development. Sensory perception strengthened through the use of the senses such as taste, touch, smell, hearing and vision, make up the set of organs that fulfill specific functions in children, such as understanding, communicating, feeding, expressing, observe, in short they are the perfect links between the interior of the human being with the outside, which helps to remain in the constant dynamic of the survival of man.

This point of view, in the present work is considered on the educational expectations for which emphasis is made to bring to the areas of the CDI a strengthening tool not only of the teaching-learning process, but to build for the child a world full of situations where he can develop his senses after the search for knowledge, as well as his integral development, that is, to be with an integrity of knowledge, attitudes and valid abilities that help him to understand his environment (Genggong \& Ashmarita, 2018).

From the children the conditions are created to have specialists and engineers prepared with basic knowledge that from the university linking to new research projects, such as geographical projects where students use different tools they learn over the years (Rodríguez et al., 2019), these are examples that can be acquired in the teaching systems, in addition to linking the processes of environmental sustainability in the teaching-learning process., that is appropriate to incorporate aspects of the surrounding environment and concepts of sustainability among the recreational corners (Vázquez, 2018; Haswadi et al., 2018). The objective of the research is to assess the need to create spaces for child support from their first years of life.

\section{Materials and Methods}

A non-experimental, descriptive study, carried out from June to July 2018, with the educators (s) who carry out their work in initial education in the various CDIs of the rural areas of the Portoviejo canton. We worked with a sample of 5 Children's Centers, intentionally selected, these were: CDI Lunita, New Friends, My first pranks, Estrellita de mar, and Nueva semilla. A survey was applied to determine the extent to which educators use innovative teaching materials, as a playful sensory strategy that favors the process of early stimulation in boys and girls. In order to determine the survey, the types of teaching materials used in the process of teaching-learning, as well as the level of knowledge that educators had about the benefits achieved with students. Prior to the application of the instrument, a pilot test was carried out with 5 educators, where it was identified that the questions had a logical order, correct statements, understandable, and there was no rejection of the questions raised. This validated the content since the items correspond to the indicators to be measured. 


\section{Results and Discussions}

$100 \%$ of educators expressed the non-existence of sensory corners in the CDI. $100 \%$ of educators expressed the non-existence of sensory corners in the CDI, this as a starting point to the analysis and assessment that these tools should be introduced at different levels of education.

In figure 1, it is shown how $80 \%$ of educators do not handle a solid knowledge related to the importance of sensory recreational corners to develop playful learning experiences appropriate to the child's perceptual stimulation.

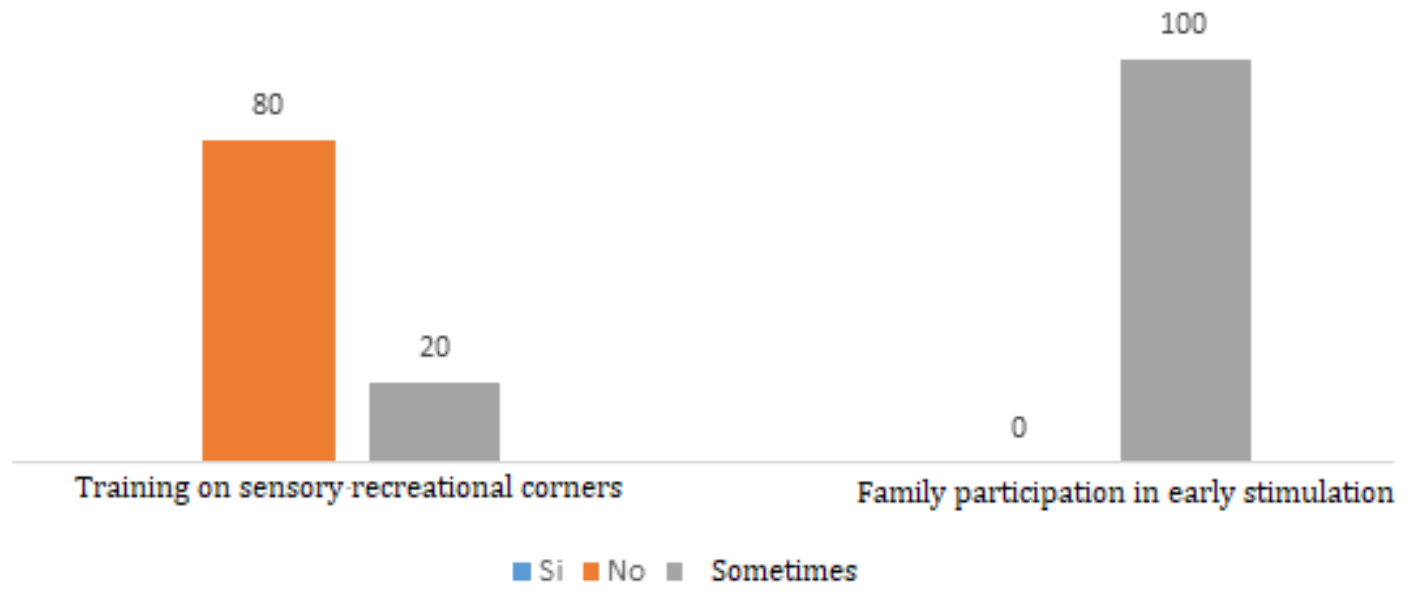

Figure 1. Training and Participation

95\% of educators believe that Coordinators should implement pedagogical innovation projects focused on sensory perception in the stimulation of boys and girls. As shown in figure 2 .

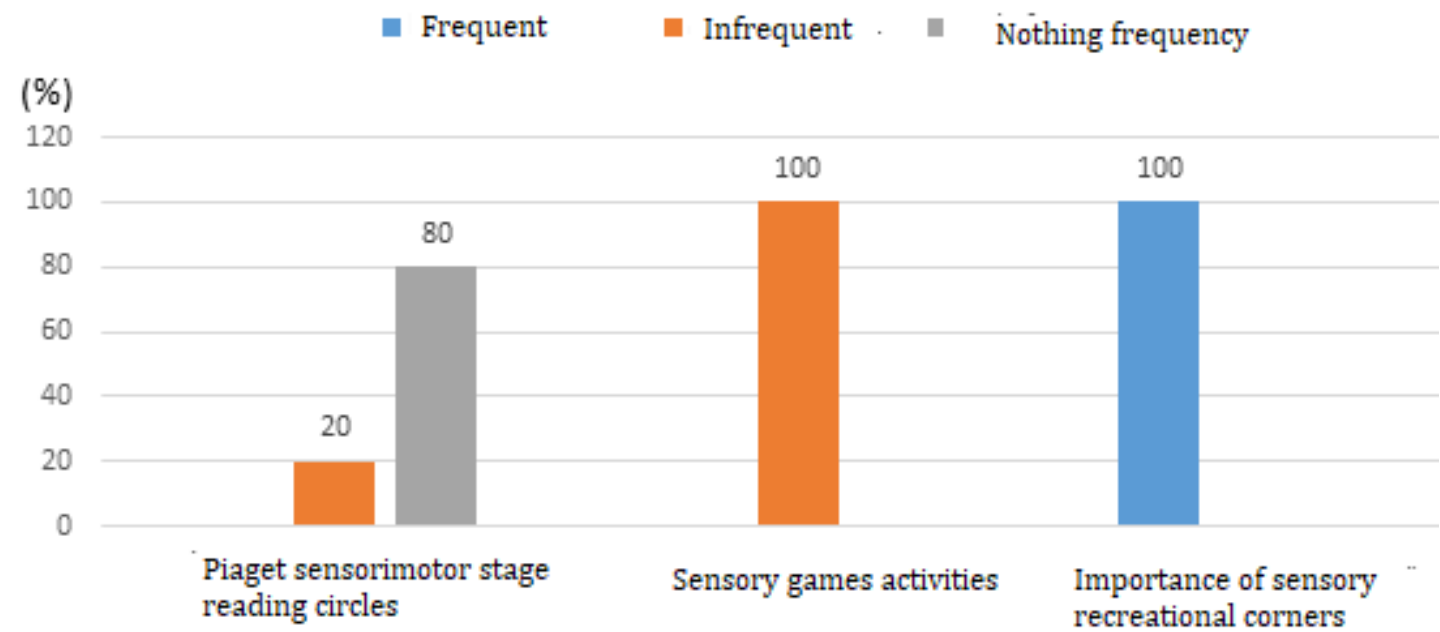

Figure 2. Reading circles, Game activities, and sensory corners

95\% of educators believe that the Coordinators must implement pedagogical innovation projects focused on sensory perception in the stimulation of children with different topics such as; gymnastics, construction,

Giler, R. D. G., Zambrano, T. Y. M., Anzules, F. E. V., \& Burgos, V. D. P. Z. (2019). Sensory playful corners on stimulation of children from one to three years. International Journal of Social Sciences and Humanities, 3(2), $217-$ 
reading, at home, in the sand, music, in figure 3 the results obtained in the surveys are shown taking into account the playful corners of the children's center.

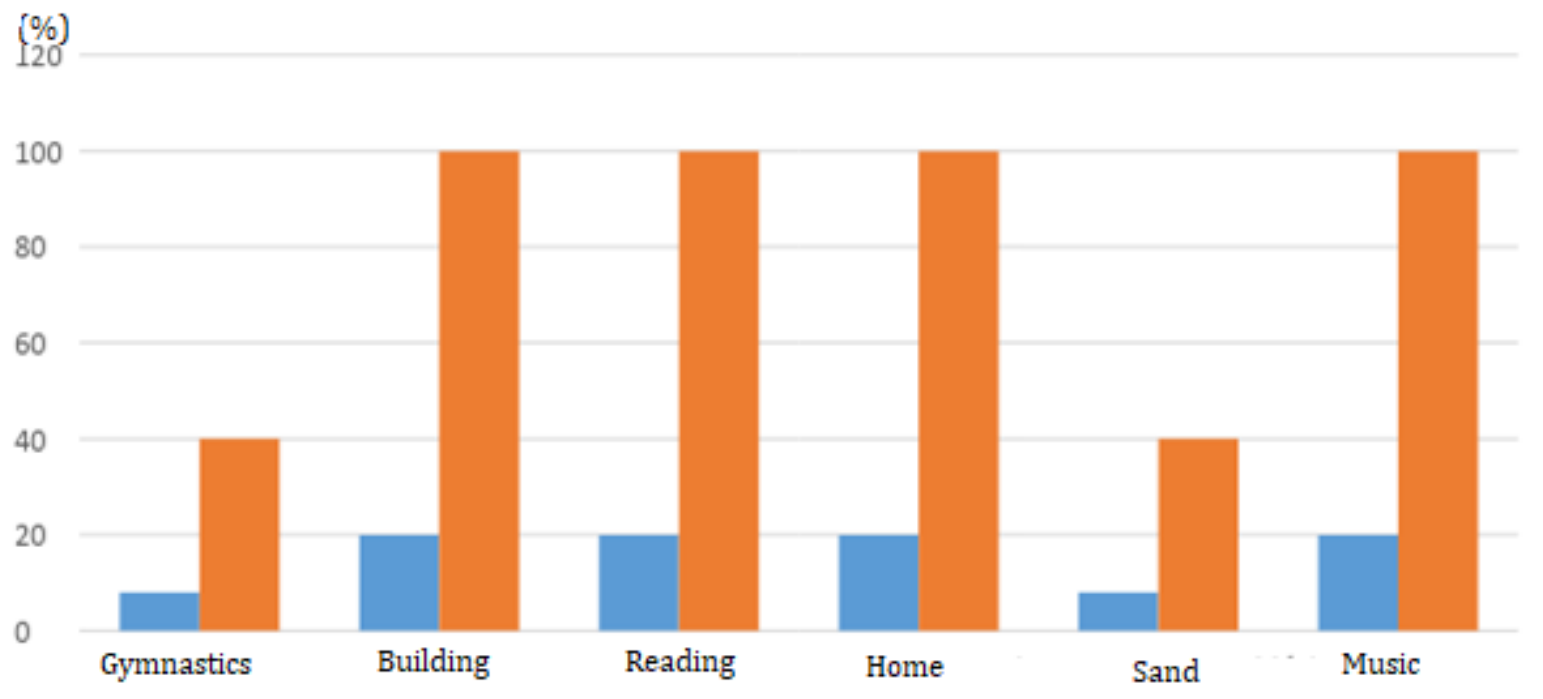

Figure 3. Playful corners of the children's center

Among the studies carried out, it was contacted that the professors suggested that these environments of the corners should be renewed semiannually so that the students could know these in the study stage.

This innovative project was proposed as a response to an urgent need for change in the actions of educators, regarding how the theme of sensory activities is being handled in the stimulation of children in their first years of life and in this way create meaningful learning in a positive way. The sensation has the great task of receiving information from the outside through the senses; Perception, on the other hand, fulfills the role of taking information to the brain, activating it to process information, elaborating responses that will generate behaviors and behaviors according to the environment that is created.

According to Rafael Linares (2008), Piaget was a phase theoretician who divided cognitive development into four major stages: sensory-motor stage, preoperational stage, stage of concrete operations and stage of formal operations, each of which represents the transition to a more complex and abstract way of knowing. In the sensory-motor stage, the baby is related to the world through the senses and the action, but at the end of this stage, he will be able to represent reality mentally. The motor sensory period gives rise to some milestones in intellectual development. Children develop intentional or goal-directed behavior (hit a rattle to make it sound). Also, children will come to understand that objects have a permanent existence that is independent of their perception (object permanence).

According to Gomez \& Fenoy (2016), The senses are open doors to the world and to reality, that is, it is the communication channel between the individual and their environment, the world we build is, therefore, the result of this perception. This construction of the subjective world and dependent on perception highlight the need for stimulation and education at an early age. González (2011), assures that: In the first years of life, the senses are the means that allow children to know the world around them. As they develop their senses, they progress in the knowledge and construction of an ever more complete physical and social world.

For Gomez et al., (2017), sensory stimulation in the first years of the life of boys and girls creates meaningful learning in a positive way. The sensation has the great task of receiving information from the outside through the senses; perception, on the other hand, fulfills the role of taking information to the brain, activating it to process information, elaborating responses that will generate behaviors and behaviors according to the environment that is created. In this order of ideas, sensory stimulation favors learning, as highlighted below: Life in relation to the world that surrounds the child begins through the senses and feelings begins your mind to build your own ideas; therefore, from the beginning, it is necessary to guide the interpretation of sensory impressions, in the clarification of sensitive perceptions. Sensory stimulation is given thanks to the union of perception and the senses thus creating a way for learning (Soler, 1992; Tjiang et al., 2018). 
In the process of education, the child assimilates different actions. Learn to dry with a towel, to eat with a spoon, among others. All these are practical actions, which lead to obtaining a specific external result. But at the same time, in the boy or girl, internal actions are also formed, with the help of which he examines the objects, discovers their properties, establishes how they are related to each other, shapes the idea of the game, of the drawing, of the construction, etc.

All internal actions arise as a result of the passage from outside to inside. Thanks to the internalization process, assimilation of the external actions that take place under the direction of the adult leads to the emergence and improvement of the internal psychic actions, to the progress in the psychic development. Now your world revolves around the objects you learn from by manipulating them, observing them. In this order of ideas, sensory stimulation favors learning, as highlighted below:

Life in relation to the world that surrounds the child begins through the senses and feelings begins your mind to build your own ideas; therefore, from the beginning, it is necessary to guide the interpretation of sensory impressions, in the clarification of sensory perceptions. Sensory stimulation is given thanks to the union of perception and the senses thus creating a way for learning (Soler, 1992).

On the other hand, cognitive development is a process through which learning occurs, this is born of socialization, interaction with the environment and the world around it, in this way the child perceives, organizes and acquires learning that allows him to grow both intellectually and maturely. According to Piaget (Hernández, 2016). Cognition is known as the increasingly complex subsequent acquisition of logical structures that underlie the different tasks and situations that the subject is able to be solved as it progresses in its development.

According to Ortiz (2006), cited by (Avellaneda, 2018), the evolutionary development from the contributions made by María Montessori incompatibility with the evolutionary theories of Piaget and Gessell, from 0 to 6 months, from the reflexes to sitting: responds to sounds emitted by others, from partially following an object with the sight to raising the arms when it likes; has reactions to the face of the mother, social smile, respond to words. From 6 months to the 1st year: Stand up alone, take the first steps, move objects to produce noises, scratch the paper., From looking in the mirror and imitating sounds and actions of the mother, pointing and vocalizing, eat a cookie, hold the bottle, cooperate to get dressed, start social game, separation anxiety. At 18 months they carry and embrace an object, walk in coordination, kick the ball, climb stairs, build 4-piece towers, try to imitate writing strokes, try to feed themselves. At 2 years they perform a parallel game, decreases separation anxiety, says: no! At 3 years old he understands the shifts, copies crosses and circles.

Torio (1997), says that children are allowed to choose the activities they want to perform, within the limits of sharing the different possibilities with others. Utensils and materials are incorporated not specifically in school but are part of the child's life. The child is considered as an active being who performs his learning through the senses and manipulation.

\section{Conclusion}

The lack of sensory recreational corners in the CDI of the Portoviejo canton causes children not to be able to relate to the environment, this need prevents the creation of better learning moments. The lack of development of sensory perception by educators working in CDI causes the need to implement a methodological guide with sessions of content, skills, playful materials for the corners of visual, auditory, taste, smell, and touch perception.

\section{Acknowledgments}

The authors would like to thank the editor of IJSSH for her valuable time, support, and advice in completing the current study.

Giler, R. D. G., Zambrano, T. Y. M., Anzules, F. E. V., \& Burgos, V. D. P. Z. (2019). Sensory playful corners on stimulation of children from one to three years. International Journal of Social Sciences and Humanities, 3(2), 217- 


\section{References}

Agudelo Gomez, L., Pulgarín Posada, LA, \& Tabares Gil, C. (2017). Sensory Stimulation in the Cognitive Development of Early Childhood. Sources, 74.

Avellaneda Acuña, CY (2018). A look at texts on Montessori pedagogy, main contributions and their applicability in children from 0 to 3 years. Universidad Católica de Pereira, 11.

Gamez, MR, Perez, AV, Falcones, VAM, \& Bazurto, JJB (2019). The geoportal as strategy for sustainable development. International Journal of Physical Sciences and Engineering, $3(1), \quad 10$ 21. https://doi.org/10.29332/ijpse.v3n1.239

Genggong, M. S., \& Ashmarita, -. (2018). Government role in development of child-friendly city based on traditional games. International Research Journal of Management, IT and Social Sciences, 5(4), 53-60. https://doi.org/10.21744/irjmis.v5n4.260

Gomez, C., \& Fenoy., B. (2016). Sensoryity as a strategy for heritage education in the. University of Valladolid (Spain). 55.

González, N., Moll, L. C., \& Amanti, C. (Eds.). (2006). Funds of knowledge: Theorizing practices in households, communities, and classrooms. Routledge.

Haswadi, M., Syarifudin, -, \& Rusdiawan, -. (2018). Children Phonological Acquisition for 3 to 5-YearOlds. International Journal of Linguistics, Literature and Culture, 4(1), 16-21.

Hernández, DMA (2016). Cognitive strategies for the understanding of expository texts in students

Ortiz, J., Romero, N., Robert, P., Araya, J., Lopez-Hernández, J., Bozzo, C., ... \& Rios, A. (2006). Dietary fiber, amino acid, fatty acid and tocopherol contents of the edible seaweeds Ulva lactuca and Durvillaea antarctica. Food chemistry, 99(1), 98-104.

Pérez, A. V., Gámez, M. R., Briones, V. F. V., Viteri, C. G. V., \& Molina, L. A. V. (2018). Sustainable development seen from environmental training in university linkage. International Journal of Life Sciences, 2(1), 12-20. https://doi.org/10.29332/ijls.v2n1.75

Rafael Linares, A. (2008). Cognitive Development: The Theories of Piaget and Vygotsky. Universitat Autònoma De Barcelona, 5.

Soler, E. (1992). Sensory Education in Early Childhood Education. Madrid: Rialp, SA.

Tjiang, N., \& Sidiartha, I. G. L. (2018). Lipid profile in obese children with and without insulin resistance. International Journal of Health Sciences, 2(2), 9-17. https://doi.org/10.29332/ijhs.v2n2.110

Torío Durántez, J., \& García Tirado, M. C. (1997). Relación médico-paciente y entrevista clínica (I): opinión y preferencias de los usuarios. Aten Primaria, 19(1), 18-26. 


\section{Biography of Authors}

\begin{tabular}{|c|c|}
\hline 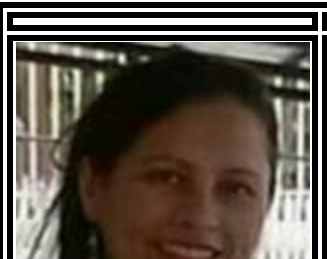 & $\begin{array}{l}\text { Rosa Delfina., } \\
\text { Master in education and social development fourth level } \\
\text { Doctor in education sciences specialty pedagogy Universdad Laica ELOY ALFARO } \\
\text { DE MANABI } \\
\text { Email: itspem.dgiler@gmail.com }\end{array}$ \\
\hline & $\begin{array}{l}\text { Telly Yarita, } \\
\text { Industrial Engineer, specialization Projects. Graduated from the Master in } \\
\text { Agricultural Engineering of the Technical University of Manabí. Teacher - } \\
\text { Responsible for the research, innovation, and technology transfer unit of the Paulo } \\
\text { Emilio Macías Higher Technological Institute } \\
\text { Email: itspem.tmacias@gmail.com }\end{array}$ \\
\hline & $\begin{array}{l}\text { Fabián Enrique, } \\
\text { Degree in informatics, Master In Educational management. Teacher / Senescyt } \\
\text { Instituto Superior Tecnológico Paulo Emilio Macías, teacher schools of police } \\
\text { professional training. } \\
\text { Email: itspem.fvera@gmail.com }\end{array}$ \\
\hline & $\begin{array}{l}\text { Veronica Del Pilar, } \\
\text { Master in Educational Development, Teacher of Instituto Superior Tecnológico } \\
\text { Paulo Emilio Macías. } \\
\text { Emal: itspem.cvillavicencio@gmail.com }\end{array}$ \\
\hline
\end{tabular}

Giler, R. D. G., Zambrano, T. Y. M., Anzules, F. E. V., \& Burgos, V. D. P. Z. (2019). Sensory playful corners on stimulation of children from one to three years. International Journal of Social Sciences and Humanities, 3(2), $217-$ 